\title{
Siklus dan Model Perkiraan Kejadian Gempabumi di Daerah Bengkulu
}

\author{
Sabar Ardiansyah ${ }^{1,2, *}$ \\ ${ }^{I}$ Stasiun Geofisika Kepahiang-Bengkulu, Jl. Pembangunan No. 156 Pasar Ujung, Kepahiang, Bengkulu 39372 \\ ${ }^{2}$ Akademi Meteorologi dan Geofisika, Jl. Perhubungan I No. 5, \\ Komplek Meteo DEPHUB, Pondok Betung, Bintaro, Tangerang 15221
}

\begin{abstract}
Intisari
Sebelum terjadi gempabumi utama, biasanya akan didahului oleh suatu pola atau siklus kegempaan. Siklus ini meliputi periode normal, periode anomali yang ditandai dengan peningkatan aktivitas, periode precursory gap yang ditandai dengan penurunan aktivitas seismik, dan periode terjadinya gempabumi utama. Tujuan dari penelitian ini adalah untuk melihat siklus kegempaan serta model (persamaan) perkiraan terjadinya gempabumi di wilayah Bengkulu untuk kegunaan mengestimasi besarnya magnitudo gempabumi yang akan terjadi berdasarkan model yang dibuat. Data yang digunakan adalah katalog data kegempaan $M>4,5$ di daerah Bengkulu pada rentang tahun 1971-2013 yang diambil melalui website USGS. Metode yang digunakan untuk perhitungan model perkiraan magnitudo gempabumi menggunakan metode Predictive Regressions dengan perhitungan regresi linier berbobot. Berdasarkan hasil analisis, model yang sudah dibuat menunjukkan bahwa diperkirakan saat ini daerah Bengkulu memilki potensi gempabumi dengan kekuatan $M>7,5$ dengan siklus kegempaan daerah Bengkulu memasuki periode precursory gap yang ditandai dengan penurunan aktivitas kegempaan.
\end{abstract}

\begin{abstract}
Before a major earthquake occurs, it will usually be preceded by a pattern or cycle of seismicity . This cycle includes a period of normal , anomalous period marked by increased activity , precursory gap period is characterized by a decrease in seismic activity, and the period of occurrence of major earthquakes . The purpose of this study is to look at seismic cycle and the model ( equation ) estimates the occurrence of earthquakes in the region for the purposes of estimating the Bengkulu earthquake magnitude that will occur based on the model created. The datas used is a catalog of seismic data for $M>4.5$ in the Bengkulu area in the range of 1971 to 2013 were taken through the USGS catalog. The method used to estimate the magnitude of an earthquake model calculations using the predictive regressions with weighted linear regression calculation. Based on the analysis, a model that has been made indicates that the current estimated Bengkulu area have the potential earthquake with the strength of $\mathrm{M}>7.5$ seismicity cycle Bengkulu area entered a period of precursory gap is characterized by a decrease in seismic activity .
\end{abstract}

KATA KUNCI: Earthquake cycle, precursors, earthquake forecast models

\section{PENDAHULUAN}

Beberapa prekursor gempabumi seperti deformasi kerak bumi, perubahan level muka air laut, regangan, tegangan kerak bumi, gempabumi pendahuluan, anomali aktivitas kegempaan, gempabumi swarm, $b$ value, perubahan kecepatan gelombang seismik, perubahan air tanah, dan gas radon merupakan fenomena yang terjadi sebagai pendahuluan sebelum terjadinya gempabumi besar $[1,2]$. Fenomena prekursor gempabumi bisa berbeda antara satu daerah dengan daerah lain [3], hal ini terjadi karena adanya perbedaan struktur geologi tiap daerah. Beberapa penelitian menunjukkan, fluktuasi perubahan aktivitas seismisitas berhubungan erat se-

\footnotetext{
*E-MAIL: sabar.ardiansyah@bmkg.go.id
}

bagai indikator prekursor gempabumi. Anomali seismisitas merupakan prekursor yang berhubungan dengan akumulasi stress atau akumulasi energi yang dapat digunakan sebagai mitigasi bencana [4]. Beberapa penelitian yang berhubungan dengan anomali seismisitas antara lain dilakukan oleh Ishida dan Kanamori [5], yang meneliti gempabumi San Fernando tahun 1971, serta penelitian yang dilakukan oleh Marza, [6] yang meneliti gempabumi tahun 1977 di Vranzea, Romania.

Prekursor kesenyapan seismisitas (seismic quiescence), menggambarkan penurunan aktivitas seismisitas, fenomena ini banyak dikaji oleh para ahli untuk memprediksi gempabumi [7, 8]. Mogi [9] melihat pola seismic quiescence sebagai aktivitas seismik yang mendahului terjadinya gempabumi besar. Berdasarkan observasi Mogi, sebelum terjadi gempabumi besar, telah terjadi aktivitas seismisitas di sekitar episenter gempabumi besar tersebut. Setelah terjadi seismic quiescence, biasanya akan diikuti dengan peningkatan gem- 


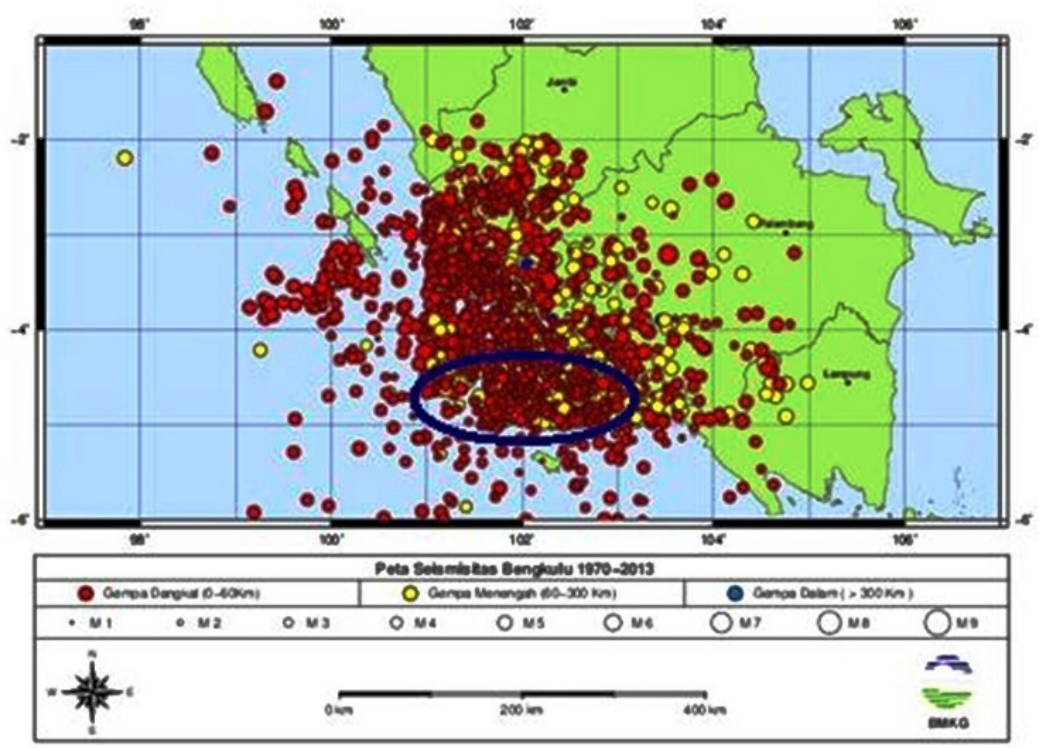

Gambar 1: Peta daerah studi (Bengkulu) serta seismisitasnya periode tahun 1971-2013. Lingkaran pada gambar merupakan fokus wilayah penelitian yang akan dibuatkan model perkiraan kejadian gempabumi.

pabumi sebagai gempabumi pendahuluan (foreshock). Aktivitas foreshock merepresentasikan pergerakan mikro lempeng bumi (micro-cracking) sebelum terjadi rupture.

Peningkatan aktivitas seismisitas sebagai gempabumi pendahuluan merupakan bagian dari siklus gempabumi. Aktivitas ini disebut sebagai anomali seismisitas (swarm). Aktivitas swarm biasanya berasosiasi dengan aktivitas vulkanik, namun bisa juga berasosiasi dengan aktivitas non-vulkanik [10]. Periode gempabumi swarm biasanya terjadi beberapa waktu di sekitar wilayah episenter gempabumi besar sebelum terjadi gempabumi besar tersebut [11]. Pada tahun 1982 Evison pernah mengusulkan hipotesis tentang gempabumi swarm sebagai prekursor gempabumi berdasrkan hasil penelitiannya di daerah Jepang. Evison juga mengusulkan formula hubungan antara gempabumi swarm dan gempabumi utama berdasarkan empat gempabumi signifikan di daerah California dan sembilan gempabumi signifikan di daerah New Zealand yang dia teliti [12, 13]. Formula dari Evison ini kemudian banyak dipakai oleh beberapa peneliti untuk meneliti gempabumi di daerah lain. Misalnya yang dilakukan oleh peneliti untuk gempabumi daerah Burma Azechman, gempabumi Pamir, gempabumi daerah timur laut India [14].

Evison membuat siklus seismik menjadi empat tahapan, tahap pertama adalah aktivitas normal (normal/background), tahap kedua adalah anomali seismisitas yang ditandai peningkatan aktivitas seismik, tahap ketiga adalah seismic quiescence yaitu tahap penurunan aktivitas seismisitas, dan tahap keempat terjadinya gempabumi utama (main shock) [11]. Pada suatu kajian di daerah tertentu periode normal $(\mathrm{N})$, periode anomali $(\mathrm{A})$, periode precursory gap $(\mathrm{G})$, dan periode main-shock (M) berturut-turut ditandai dengan periode aktivitas seismik yang rendah, tinggi, rendah dan tinggi (termasuk aktivitas gempabumi susulan).

Di Indonesia kajian tentang siklus kegempaan serta model perkiraan kejadian gempabumi masih jarang dikaji baik skala regional maupun skala lokal. Sehingga kajian ini menarik untuk dilakukan di kawasan-kawasan seismik aktif seperti pantai barat Sumatera pada umumnya dan wilayah Bengkulu Khususnya. Melalui tulisan ini, penulis akan menganalisis pola aktivitas kegempaan di wilayah Bengkulu sebelum terjadi gempabumi signifikan $(M>7,0)$ untuk periode tahun 1971 hingga 2013.

\section{METODE PENELITIAN}

\section{A. Data Penelitian}

Data yang dipakai untuk analisis dalam tulisan ini menggunakan data katalog gempabumi daerah Bengkulu dan sekitarnya periode tahun 1971-2013 yang diambil dari katalog USGS [15]. Daerah studi merupakan daerah Bengkulu yang meliputi koordinat 2,0-6 LS dan 98-104 BT. Sedangkan fokus pemodelan perkiraan gempabumi adalah zona rupture gempabumi tanggal 4 Juni 2000 dan 12 September 2007 pada area 3,0-6,0 LS dan 100-104 BT yang ditandai dengan lingkaran [16] dalam Gambar 1.

\section{B. Teori Tentang Regresi Model Perkiraan Magnitudo Gempabumi (Predictive Regressions)}

Evison [17], mengusulkan formula pemodelan perkiraan magnitudo gempabumi berdasarkan penelitian di daerah New Zaeland yang dituliskan:

$$
\begin{aligned}
M_{m} & =b+a M_{p} \\
\log T_{p} & =d+c M_{p}
\end{aligned}
$$


dengan $\mathbf{M}_{m}$ adalah besarnya perkiraan magnitudo gempabumi utama yang akan terjadi, $\mathbf{M}_{p}$ adalah nilai rata-rata dua magnitudo terbesar yang terjadi selama periode anomali peningkatan seismisitas (swarm), $\mathrm{T}_{p}$ adalah lama waktu terjadi periode anomali peningkatan seismisitas (swarm) sampai terjadi gempabumi utama (dalam hari), sedangkan a, b, c, dan d adalah konstanta. Jika ditulis dalam bentuk persamaan linier secara umum:

$$
Y=m_{1}+m_{2} X
$$

Dengan menggunakan solusi regresi linier berbobot, parameter model $\left(\mathrm{m}_{1}\right.$ dan $\left.\mathrm{m}_{2}\right)$ dapat diselesaikan dengan persamaan:

$$
m=\left[\underline{G}^{T} \underline{W}_{e} \underline{G}\right]^{-1} \underline{G}^{T} \underline{W}_{e} D
$$

dengan $\underline{G}$ adalah matriks kernel, $W_{e}$ adalah matriks pembobotan dengan elemen diagonal adalah varian data, dan D adalah matriks data.

Berdasar penelitian Evison [18] untuk gempabumi daerah New Zaeland didapat konstanta $\mathrm{a}=1,04, \mathrm{~b}=1,52, \mathrm{c}=0,51$, dan $\mathrm{d}=0,64$. Evison juga meneliti gempabumi daerah Jepang dan didapat konstanta a, b, c, dan d berturut-turut 0,$72 ; 2,73$; 0,37 ; dan 1,61 .

Singh [19] juga meneliti pola atau karakteristik kegempaan sebelum terjadi gempabumi signifikan di daerah Barat Nepal, India. Berdasarkan hasil penelitian ini, karakteristik kegempaan di wilayah Nepal terdapat pola yang menarik yaitu selalu diikuti dengan siklus kegempaan yang terdiri dari siklus normal $(\mathrm{N})$, anomali seismisitas atau peningkatan aktivitas seismisitas (swarm) (A), penurunan aktivitas seismik (precursory gap) (G), dan diikuti gempabumi utama. Dari kajian ini didapat hubungan antara gempabumi utama terhadap magnitudo rata-rata saat terjadi swarm serta hubungan antara besarnya magnitudo utama $\left(\mathrm{M}_{m}\right)$ untuk daerah Nepal yang dirumuskan sebagai berikut:

$$
\begin{aligned}
M_{m} & =1,05 M_{p}+0,69 \\
\log T_{p} & =0,59 M_{p}+0,08 \\
M_{m} & =1,92 \log T_{p}+0,01
\end{aligned}
$$

Formula ini memberikan prediksi besaran magnitudo gempabumi utama yang akan terjadi jika durasi $\mathrm{T}_{p}$ dan magnitudo rata-rata $\mathrm{M}_{p}$ selama periode swarm diketahui. Formula ini memberikan hasil yang cukup baik jika selama masa periode anomali swarm tidak ada gempabumi yang terjadi dengan magnitudo lebih besar atau sama dengan magnitudo $\mathbf{M}_{p}$. Berdasarkan penelitian Singh [20] rangkaian gempabumi swarm terjadi pada area yang akan menjadi zona rupture gempabumi utama yang akan terjadi.

Setelah terjadi rangkaian gempabumi swarm atau peningkatan aktivitas seismisitas, periode selanjutnya diikuti dengan periode penurunan aktivitas (seismic quiescence) yang merupakan periode pengumpulan energi atau akumulasi stress sampai terjadi gempabumi utama. Lamanya waktu (dalam hari) terjadinya aktivitas swarm dijadikan sebagai parameter untuk mengestimasi besarnya gempabumi utama yang akan terjadi berdasarkan persamaan hubungan antara $\mathbf{M}_{m}$ dan $\mathbf{T}_{p}$ atau hubungan antara $\mathbf{M}_{m}$ dan $\mathbf{M}_{p}$.
TABEL I: Karakteristik kegempaan daerah Bengkulu ( $\mathrm{M}>4,5)$ sebelum terjadi gempabumi tanggal 1 Oktober 1975, $\mathrm{M}=7,0$ [15]

\begin{tabular}{llll}
\hline \hline $\begin{array}{l}\text { Seismic } \\
\text { episodes }\end{array}$ & Duration & $\begin{array}{l}\text { Total } \\
\text { Days }\end{array}$ & $\begin{array}{c}\text { Evevel of } \\
\text { Activity }\end{array}$ \\
\hline $\begin{array}{l}\text { 1. Normal/back- 1 Januari 1971- } \\
\text { ground (N) }\end{array}$ & $\begin{array}{l}\text { 31 Desember 1971 } \\
\text { 365 }\end{array}$ & 9 & Low \\
$\begin{array}{l}\text { 2. Anomalous/ } \\
\text { 1 Januari 1972- }\end{array}$ & & \\
$\begin{array}{l}\text { swarm (A) } \\
\text { 31 Desember 1972 }\end{array}$ & 365 & 34 & High \\
$\begin{array}{l}\text { 3. Precursory } \\
\text { gap }(\mathrm{G})\end{array}$ & $\begin{array}{l}\text { 1 Januari 1973- } \\
\text { 30 September 1974 } 635\end{array}$ & 20 & Low \\
$\begin{array}{l}\text { 4. Main-shock } \\
\text { sequence (M) }\end{array}$ & 1 Oktober 1975 & & \\
\hline \hline
\end{tabular}

\section{HASIL DAN PEMBAHASAN}

Berdasarkan hasil pengolahan data katalog gempabumi daerah Bengkulu tahun 1971 hingga 2013, terdapat pola yang menarik sebelum terjadi gempabumi utama $(M>7,0)$. Pola atau siklus yang terjadi adalah dimulai dari aktivitas normal, kemudian diikuti dengan anomali seismisitas dengan indikasi peningkatan seismisitas (swarm), periode selanjutnya adalah periode penurunan aktivitas seismisitas, dan periode selanjutnya adalah periode terjadinya gempabumi utama. Pola ini ditampilkan pada Gambar 2.

Pada Gambar 2 memperlihatkan bahwa setiap sebelum terjadi gempabumi utama tahun 1975, 1994, 2000, dan 2007 (yang ditandai panah) selalu didahului oleh siklus penurunan aktivitas kegempaan. Lamanya priode tiap-tiap siklus cukup bervariasi yang akan dijabarkan pada pembahasan berikut.

\section{Karakteristik Kegempaan Sebelum Gempabumi 1 Oktober $1975(\mathrm{M}=7,0)$}

Gempabumi 1 Oktober 1975 terletak pada koordinat 4,88 LS 102,19 BT dengan kedalaman $33 \mathrm{~km}$. Sebelum terjadi gempabumi utama tanggal 1 Oktober 1975 dengan kekuatan $\mathrm{M}=7,0$ ini, siklus kegempaan dimulai dari periode normal selama periode 1 Januari 1971 hingga 31 Desember 1971 (365 hari) gempabumi dengan kekuatan $M>4,5$ hanya terjadi 9 event. Siklus selanjutnya diikuti dengan periode peningkatan aktivitas seismisitas (swarm) selama 1 Januari 1972 hingga 31 Januari 1972 (365 hari) terjadi gempabumi dengan kekuatan M > 4,5 sebanyak 34 event. Setelah periode swarm, siklus selanjutnya adalah seismic quiescence yang ditandai dengan penurunan aktivitas kegempaan. Periode ini berlangsung selama 1 Januari 1973 hingga 30 September 1975 (635 hari) jumlah event $M>4,5$ yang terjadi pada periode ini hanya 20 event (lihat Tabel I). Selama periode swarm, dua gempabumi terbesar yang terjadi adalah $\mathrm{M}=6,0$ dan $\mathrm{M}=5,4$ sehingga magnitudo rata-rata $\left(\mathrm{M}_{p}\right)$ adalah $\mathrm{M}=5,7$.

\section{Karakteristik Kegempaan Sebelum Gempabumi 15 Februari $1994(M=7,0)$}

Gempabumi 15 Februari 1994 berkekuatan 7,0 terletak pada koordinat 4,97 LS 104,30 BT dengan kedalaman $23 \mathrm{~km}$. 


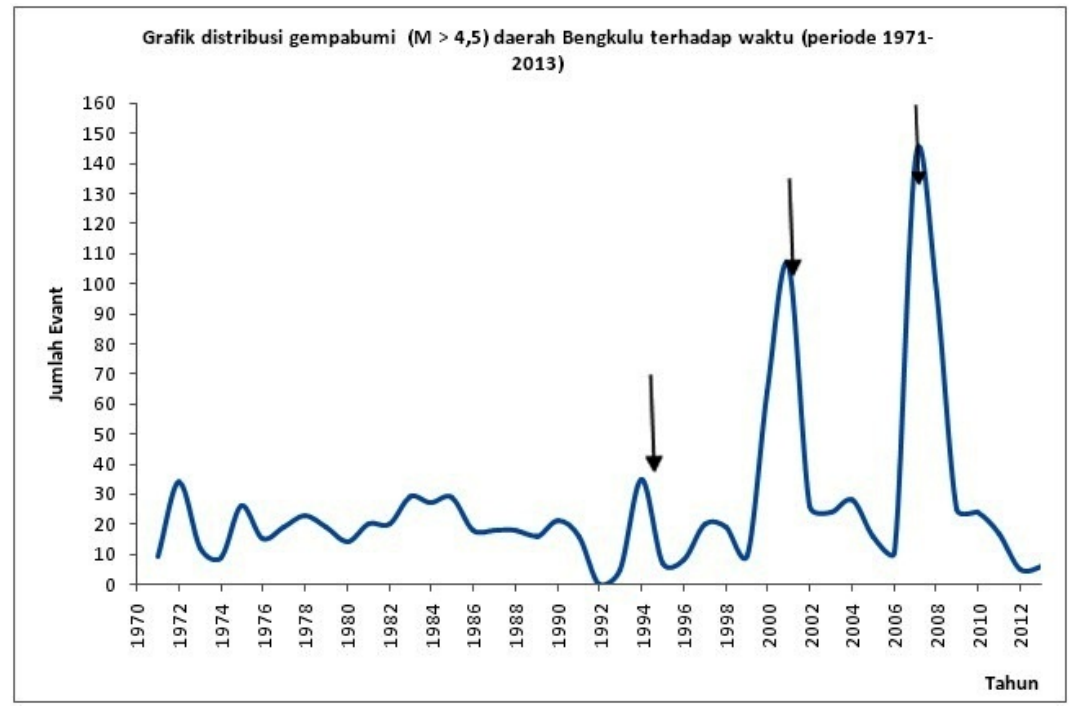

Gambar 2: Grafik distribusi gempabumi (M > 4,5) daerah Bengkulu periode tahun 1971-2013.

TABEL II: Karakteristik kegempaan daerah Bengkulu (M > 4,5) sebelum terjadi gempabumi tanggal 15 Februari 1994, $\mathrm{M}=7,0$ [15].

\begin{tabular}{|c|c|c|c|c|}
\hline $\begin{array}{l}\text { Seismic } \\
\text { episodes }\end{array}$ & Duration & Days & $\begin{array}{l}\text { Total } \\
\text { Events }\end{array}$ & $\begin{array}{l}\text { Level of } \\
\text { Activity }\end{array}$ \\
\hline $\begin{array}{l}\text { 1. Normal/back- } \\
\text { ground }(\mathrm{N})\end{array}$ & $\begin{array}{l}\text { 1 Januari 1976- } \\
\text { 31 Desember } 1981\end{array}$ & 2190 & 110 & Low \\
\hline $\begin{array}{l}\text { 2. Anomalous/ } \\
\text { swarm (A) }\end{array}$ & $\begin{array}{l}1 \text { Januari 1982- } \\
31 \text { Desember } 1985\end{array}$ & 1460 & 105 & High \\
\hline $\begin{array}{l}\text { 3. Precursory } \\
\text { gap }(\mathrm{G})\end{array}$ & $\begin{array}{l}1 \text { Januari 1986- } \\
14 \text { Pebruari } 1994\end{array}$ & 2920 & 112 & Low \\
\hline $\begin{array}{l}\text { 4. Main-shock } \\
\text { sequence }(\mathrm{M})\end{array}$ & $\begin{array}{l}15 \text { Pebruari 1994- } \\
31 \text { Desember } 1994\end{array}$ & & & \\
\hline
\end{tabular}

Sama seperti siklus gempabumi tanggal 1 Oktober 1975, sebelum terjadi gempabumi 15 Februari 1994 juga mengikuti pola yang sama. Dimulai dari periode normal, yaitu selama 1 Januari 1976 - 31 Desember 1981 (2190 hari) jumlah event (M > 4,5) yang terjadi 110 event, kemudian diikuti periode swarm atau peningkatan aktivitas seismisitas dimana pada perode 1 Januari 1982 - 31 Januari 1985 (1460 hari) jumlah event yang terjadi mencapai 105 event, selama periode ini dua magnitudo terbesar yang terjadi dengan kekuatan 6,6 dan 6,5 dengan $\mathrm{Mp}=6,55$. Periode seismic quiescence terjadi selama 1 Januari 1986 - 14 Februari 1994 (2920 hari) jumlah event yang terjadi sebanyak 112. Karakteristik kegempaan sebelum gempabumi 15 Februari 1994 dapat dilihat pada Tabel II.

\section{Karakteristik Kegempaan Sebelum Gempabumi 4 Juni $2000(M=7,9)$}

Gempabumi tanggal 4 Juni 2000 merupakan salah satu gempabumi yang menyebabkan banyak korban jika kerusakan di daerah Bengkulu. Gempabumi ini terletak pada koordinat 4,72 LS 102,04 BT pada kedalaman $33 \mathrm{~km}$. Lima tahun sebelum terjadi gempabumi utama, terindikasi adanya siklus yang teratur sebagai prekursor gempabumi ini. Dimulai dari
TABEL III: Karakteristik kegempaan daerah Bengkulu ( $\mathrm{M}>4,5)$ sebelum terjadi gempabumi tanggal 4 Juni 2000, $M=7,9$ [15].

\begin{tabular}{|c|c|c|c|c|}
\hline $\begin{array}{l}\text { Seismic } \\
\text { episodes }\end{array}$ & Duration & Days & $\begin{array}{l}\text { Total } \\
\text { Events }\end{array}$ & $\begin{array}{l}\text { Level of } \\
\text { Activity }\end{array}$ \\
\hline $\begin{array}{l}\text { 1. Normal/back- } \\
\text { ground }(\mathrm{N})\end{array}$ & $\begin{array}{l}\text { 1 Januari 1995- } \\
31 \text { Desember } 1996\end{array}$ & 730 & 15 & Low \\
\hline $\begin{array}{l}\text { 2. Anomalous/ } \\
\text { swarm (A) }\end{array}$ & $\begin{array}{l}1 \text { Januari } 1997- \\
31 \text { Desember } 1997\end{array}$ & 365 & 39 & High \\
\hline $\begin{array}{l}\text { 3. Precursory } \\
\operatorname{gap}(\mathrm{G})\end{array}$ & $\begin{array}{l}1 \text { Januari 1998- } \\
3 \text { Juni } 2000\end{array}$ & 515 & 13 & Low \\
\hline $\begin{array}{l}\text { 4. Main-shock } \\
\text { sequence }(\mathrm{M})\end{array}$ & $\begin{array}{l}4 \text { Juni } 2000- \\
31 \text { Desember } 2000\end{array}$ & & & \\
\hline
\end{tabular}

periode normal selama dua tahun, 1 Januari 1995 - 31 Desember 1996 (730 hari) gempabumi dengan kekuatan $\mathrm{M}>4,5$ hanya 15 event. Setelah periode normal ini, kemudian diikuti dengan periode anomali seismisitas atau peningkatan aktivitas seismik (swarm) selama satu tahun mulai 1 Januari 1997 - 31 Desember 1997 (365 hari) jumlah event $M>4,5$ yang terjadi sebanyak 39 event dengan $\mathbf{M}_{p}=6,5$. Setelah periode swarm, kemudian diikuti periode penurunan aktivitas seismik (precursory gap) selama 1 Januari 1988 - 3 Juni 2000 (515 hari) dengan jumlah event $M>4,5$ hanya 13 event. Secara lengkap karekteristik kegempaan sebelum terjadi gempabumi tanggal 4 Juni 2000 ditabelkan pada Tabel III.

\section{Karakteristik Kegempaan Sebelum Gempabumi 12 September $2007(M=8,5)$}

Gempabumi tanggal 12 September 2007 dengan kekuatan 8,5 $\mathrm{M}_{w}$ merupakan gempabumi besar yang juga mengakibatkan kerusakan di daerah Bengkulu. Gempabumi ini terletak pada koordinat 4,52 LS 101,37 BT pada kedalaman 34 $\mathrm{km}$. Dilihat dari siklus seismik, pola kegempaan sebelum terjadi gempabumi utama berbeda dengan tiga gempabumi signifikan sebelumnya. Tabel IV menyajikan karakteristik 
TABEL IV: Karakteristik kegempaan daerah Bengkulu $(\mathrm{M}>4,5)$ sebelum terjadi gempabumi tanggal 12 September $2007, M=8,5$ [15].

\begin{tabular}{lllll}
\hline \hline $\begin{array}{l}\text { Seismic } \\
\text { episodes }\end{array}$ & Duration & $\begin{array}{l}\text { Total } \\
\text { Days }\end{array}$ & $\begin{array}{l}\text { Level of } \\
\text { Ectivity }\end{array}$ \\
\hline $\begin{array}{l}\text { 1. Anomalous/ } \\
\text { swarm (A) }\end{array}$ & $\begin{array}{l}\text { 1 Januari 2001- } \\
\text { 31 Desember 2004 }\end{array}$ & 1460 & 184 & High \\
$\begin{array}{l}\text { 2. Precursory } \\
\text { 1 Januari 2005- }\end{array}$ & & & \\
$\begin{array}{l}\text { gap }(\mathrm{G}) \\
\text { 11 September 2007 }\end{array}$ & 981 & 36 & Low \\
$\begin{array}{l}\text { Main-shock } \\
\text { sequence (M) }\end{array}$ & 12 September 2007- & & \\
\hline \hline
\end{tabular}

kegempaan sebelum terjadi gempabumi utama 12 Sepember 2007. Pada tabel dapat dilihat, sebelum gempabumi utama hanya ada dua siklus yaitu siklus anomali peningkatan aktivitas seismik (swarm) dan siklus penurunan aktivitas seismik (precursory gap). Periode anomali swarm (A) berlangsung selama 1 Januari 2001 - 31 Desember 2004 (1460) dengan total event $\mathrm{M}>4,5$ yang terjadi sebanyak 184 event, dan $\mathbf{M}_{p}=7,1$. Periode penurunan aktivitas seismisitas berlangsung selama 1 Januari 2005 - 11 September 2007 (981 hari) dengan total event $\mathrm{M}>4,5$ yang terjadi hanya 36 event. Setelah periode seismic quiescence, tepat pada tanggal 12 September 2007 terjadi gempabumi utama $\left(\mathrm{M}_{m}\right)$ dengan kekuatan 8,5 $\mathbf{M}_{w}$.

\section{Regresi Formula Perkiraan Magnitudo Gempabumi di Wilayah Bengkulu (Predictive Regressions)}

Berdasarkan parameter masing-masing karakteristik kegempaan sebelum terjadi gempabumi utama, maka bisa dihitung formula yang menyatakan hubungan antara magnitudo rata-rata saat terjadi periode swarm $\left(\mathrm{M}_{p}\right)$ terhadap lamanya periode swarm $\left(\mathrm{T}_{p}\right)$. Begitu juga dengan hubungan antara magnitudo gempabumi utama yang akan datang $\left(\mathrm{M}_{m}\right)$ terhadap magnitudo rata-rata saat periode swarm $\left(\mathrm{M}_{p}\right)$, serta hubungan antara $\mathrm{T}_{p}$ dan $\mathrm{M}_{m}$ dapat dihitung dengan metode lest square. Pada Gambar 3 memperlihatkan hasil perhitungan yang telah dilakukan.

Dari Gambar 3 ditunjukkan hasil perhitungan model kegempaan di wilayah Bengkulu yang dapat ditulis sebagai berikut:

$$
\begin{aligned}
M_{m} & =0,993 M_{p}+1,182 ;\left(R^{2}=0,606\right) \\
\log T_{p} & =0,267 M_{p}+1,435 ;\left(R^{2}=0,868\right) \\
\log T_{p} & =0,177 M_{m}+1,822 ;\left(R^{2}=0,555\right)
\end{aligned}
$$

Pers. (8) dan (10) memperlihatkan bahwa estimasi besarnya magnitudo gempabumi utama $\left(\mathrm{M}_{m}\right)$ diwaktu yang akan datang dapat dicari jika $\mathrm{M}_{p}$ dan $\mathrm{T}_{p}$ diketahui. Artinya dugaan besarnya magnitudo gempabumi utama bisa dihitung jika siklus kegempaan pada periode swarm telah dilewati sebelum terjadinya gempabumi utama. Menurut Singh [19] kondisi ini hanya berlaku jika pada masa siklus senyap atau penurunan aktivitas kegempaan tidak ada gempabumi dengan magnitudo lebih besar atau sama dengan magnitudo $\mathbf{M}_{p}$. Dengan adanya magnitudo yang lebih besar atau sama dengan $\mathbf{M}_{p}$ pada saat periode precursory gap berarti akan mengurangi

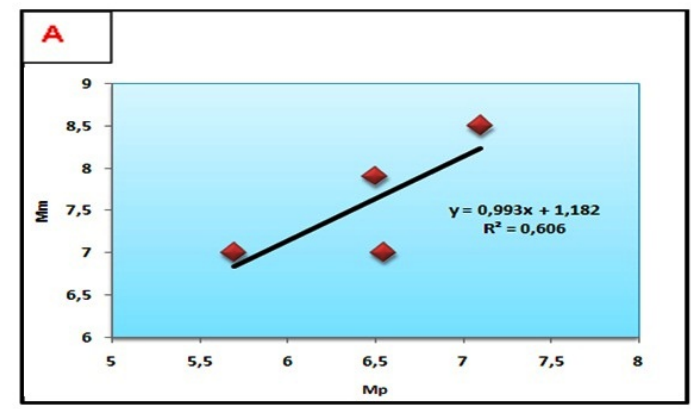

(a) Kurva hubungan antara $\mathbf{M}_{m}$ dan $\mathrm{M}_{P}$

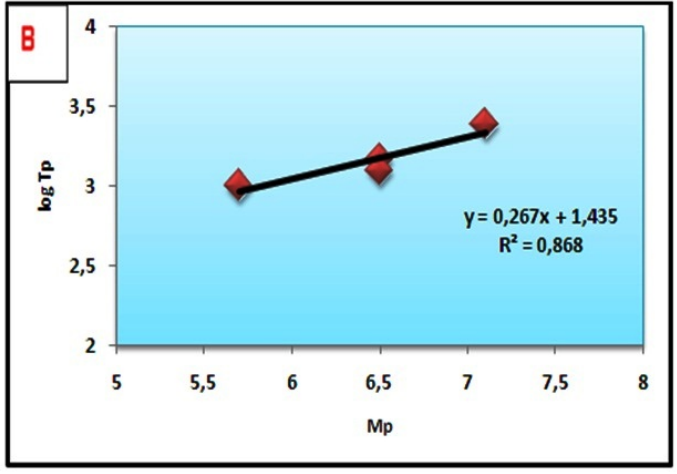

(b) Kurva hubungan antara $\mathrm{M}_{p}$ dan $\mathrm{T}_{P}$

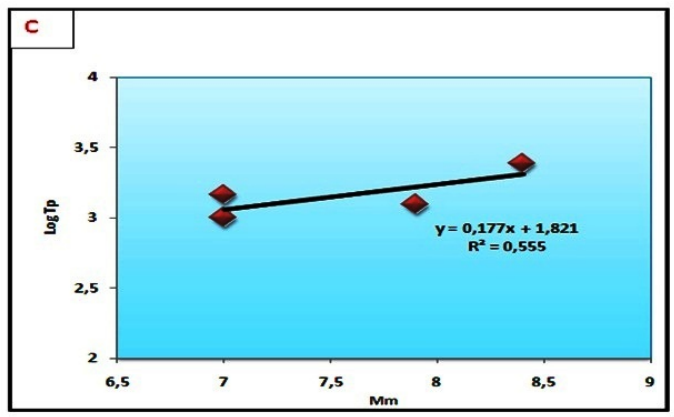

(c) Kurva hubungan antara $\mathrm{M}_{m}$ dan $\log \mathrm{T}_{P}$

Gambar 3: Kurva hubungan antara $\mathbf{M}_{m}$ (magnitudo gempabumi utama), $\mathbf{M}_{P}$ (nilai rata-rata dua magnitudo terbesar yang terjadi selama masa swarm), dan log $\mathrm{T}_{P}$ (lama waktu terjadinya periode swarm)

akumulasi stress pada patahan. Kondisi ini akan memperpanjang siklus precursory gap yang akan mengakibatkan peluang terjadinya gempabumi utama $\left(\mathrm{M}_{m}\right)$ dengan magnitudo yang lebih besar [19] . Jika kondisi ini terjadi maka diperlukan pertimbangan dan faktor lain untuk mengestimasi besarnya magnitudo gempabumi utama $\left(\mathrm{M}_{m}\right)$.

Menurut Rikitake $[1,21]$ besarnya magnitudo gempabumi utama berbanding lurus dengan logaritma lamanya waktu periode terjadinya prekursor (sejak terjadi periode swarm hingga terjadi gempabumi utama). Pers.(10) dan Gambar 3(c) memperlihatkan hubungan linier antara $\mathrm{M}_{m}$ terhadap $\mathrm{T}_{p}$. Pola anomali seismisitas dan relasi antara $\mathrm{M}_{m}$ dan $\mathrm{T}_{p}$ ini bisa dijadikan salah satu metode untuk dijadikan sebagai prekursor gempabumi jangka panjang. 
TABEL V: Karakteristik kegempaan daerah Bengkulu $(M>4,5)$ saat ini. Periode 13 September 2007-31 Desember 2013 [15].

\begin{tabular}{|c|c|c|c|c|}
\hline $\begin{array}{l}\text { Seismic } \\
\text { episodes }\end{array}$ & Duration & Days & $\begin{array}{l}\text { Total } \\
\text { Events }\end{array}$ & $\begin{array}{l}\text { Level of } \\
\text { Activity }\end{array}$ \\
\hline $\begin{array}{l}\text { 1. Normal/back- } \\
\text { ground }(\mathrm{N})\end{array}$ & $\begin{array}{l}13 \text { September 2007- } \\
31 \text { Desember } 2008\end{array}$ & & & \\
\hline $\begin{array}{l}\text { 2. Anomalous/ } \\
\text { swarm (A) }\end{array}$ & $\begin{array}{l}\text { 1 Januari 2009- } \\
\text { 31 Desember } 2011\end{array}$ & 730 & 184 & High \\
\hline $\begin{array}{l}\text { 3. Precursory } \\
\text { gap }(\mathrm{G}) \\
\text { 4. Main-shock } \\
\text { sequence }(\mathrm{M})\end{array}$ & $\begin{array}{l}1 \text { Januari } 2012 \text { to } \\
\text { continuing }\end{array}$ & 730 & 11 & Low \\
\hline
\end{tabular}

\section{Karakteristik Kegempaan Daerah Bengkulu Saat Ini}

Periode terjadinya gempabumi utama 12 September 2007 beserta gempabumi susulannya berlangsung cukup lama hingga mencapai akhir tahun 2008. Hal ini dapat dilihat dari aktivitas kegempaan $\mathrm{M}>4,5$ masih tergolong tinggi dengan total event yang terjadi mencapai 133 event pada tahun 2007, dan 100 event pada tahun 2008. Periode swarm dimulai sejak 1 Januari 2009 hingga 31 Desember 2011. Dalam waktu dua tahun ini (730 hari) jumlah event $\mathrm{M}>4,5$ tercatat sebanyak 184 event dengan $\mathrm{M}_{p}=6,4$. Periode penurunan aktivitas seismik terindikasi sejak 1 Januari 2012 hingga sekarang. Dalam rentang waktu dua tahun ini (730 hari) jumlah event $\mathrm{M}>4,5$ yang tercatat hanya 11 event. Periode ini dapat diinterpretasikan sebagai periode pengumpulan energi atau akumulasi stress seperti ditampilkan pada Tabel V.

Dari formula yang sudah dihitung di atas, maka wilayah Bengkulu saat ini diperkirakan memiliki potensi gempabumi dengan kekuatan $M>7,5$. Beberapa hasil penelitian sebelumnya juga menunjukkan bahwa setelah terjadi gempabumi 12 September 2007, saat ini di kawasan Bengkulu dalam tahap akumulasi energi. Seperti penelitian yang dilakukan oleh Rohadi [22] yang melakukan perhitungan b-value baik secara temporal maupun spasial di seluruh kawasan pantai barat $\mathrm{Su}$ matera periode tahun 1973 - 2008. Hasilnya menunjukkan bahwa di wilayah Bengkulu khususnya di wilayah rupture zone gempabumi 12 September 2007 memiliki nilai b-value yang rendah. Menurut Rohadi [22] wilayah dengan b-value rendah ini berpeluang terjadinya gempabumi besar diwaktu yang akan datang.

\section{SIMPULAN}

Berdasarkan analisis katalog data gempabumi periode 1971-2013 di daerah Bengkulu, telah terindikasi adanya pola atau siklus yang teratur sebelum terjadinya gempabumi utama yang signifikan. Siklus ini mengikuti pola meliputi periode normal $(\mathrm{N})$, periode anomali peningkatan seismisitas (A), periode penurunan aktivitas seismik atau precursory gap $(\mathrm{G})$, dan periode terjadinya gempabumi utama (M). Berdasarkan studi ini, karakteristik kegempaan di daerah Bengkulu bisa dijadikan salah satu metode untuk prekursor gempabumi jangka panjang dalam upaya mitigasi bencana. Siklus kegempaan di daerah Bengkulu saat ini dalam periode precursory gap $(\mathrm{G})$ atau periode penurunan aktivitas seismik. Berdasarkan perhitungan menggunakan formula hubungan antara $\mathrm{M}_{p}, \mathrm{M}_{m}$, dan $\mathrm{T}_{p}$ yang telah didapat, maka saat ini daerah Bengkulu diperkirakan menyimpan potensi gempabumi dengan kekuatan $\mathrm{M}>$ 7,5 .
[1] T. Rikitake, Earthquake Forecasting and Warning (Center for Academic Publications Japan 3, 402, 1982).

[2] T. Rikitake, Earthquake Prediction (Elsevier Amsterdam, pp. 257, 1976)

[3] T. Lay, and T.C. Wallace, Modern Global Seismology (International Geophysics Series, Vol 58, Academic Press, San Diego, 1995).

[4] H. Sekiya, Journal Physical Earth, 25, 85-93 (1977).

[5] M. Ishida, and H. Kanamori, Geophys. Ress. Lett., 4, 345-346 (1977).

[6] V.I. Marza, Tectonophysics, 53, 217-222 (1979).

[7] R.E. Habermann, Pure and Appl. Geophysics, 126, 279-318 (1988).

[8] R.E. Habermann, and M. Wyss, Journal Geophysics Research, 92, 9446-9450 (1987).

[9] K. Mogi, Earthquake Prediction (Academic Press, San Diego, pp. 355,1985$)$

[10] K.E. Bullen,and B.A. Bolt, An Introduction to the Theory of Seismology (Cambridge University Press, pp.499, 1985).

[11] F.F. Evison, Nature, 266, 710-712 (1977).

[12] F.F. Evison, Physical Earth Planet Inter., 15, 19-23 (1977).
[13] F.F. Evison, and D.A. Rhoades, Earth Planet Space, 51, 12671277 (1999).

[14] H.K. Gupta, and H.N Singh, Journal Geology Soc. India, 28, 367-406 (1986).

[15] Source Parameter Search, 2013. (http://earthquake.usgs.gov/ eartquakes/ eqarchives/ sopar/),diakses: 29 Desember 2013.

[16] Zona Rupture Gempa Bengkulu 4 Juni 2000. (http: //www. dbriptek.ristek.go.id/cgi/ penjaga.cgi?tampildetil \& publikasi \& 1111879394\&1086), diakses tanggal: 17 Desember 2013.

[17] F.F. Evison, Journal Physical Earth, 30, 155-170 (1982).

[18] F.F. Evison, and D.A. Rhodes, Journal Geology. Geophysic, 40, 537-547 (1977).

[19] H.N. Singh, et al., Pure and Applied Geophysics, 167, 667-684 (2010).

[20] V.P. Singh, and H.N. Singh, Earthq Predict Res., 2, 245-258 (1984).

[21] T. Rikitake, Tectonophysics, 54, 293-309 (1978).

[22] Rohadi, Supriyanto, H. Grandis, dan M.A. Ratag, Jurnal Meteorologi dan Geofisika, 9(2), 65-77 (2008). 